\title{
Faunistic Notes at Plymouth during 1893-4.
}

With Observations on the Breeding Seasons of Marine Animals, and on the Periodic Changes of the Floating Fauna.

\author{
By
}

Walter Garstang, M.A.,

Fellow and Lecturer of Lincoln College, Oxford; late Naturalist to the Marine Biological Association.

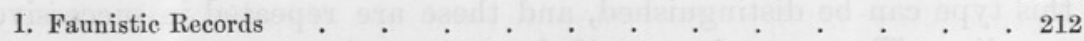

II. Notes on the Breeding Seasons of Marine Animals at Plymouth . $\quad$. $\quad$. 222

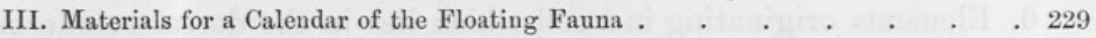

Tне year 1893 was one of exceptional interest to the marine zoologist. During the first two months Plymouth experienced a continuous succession of heavy gales, but towards the middle of March the winds became lighter, and the sea, which had been running remarkably high outside the breakwater, subsided. From that time onwards till the middle of September we enjoyed six months of the most delightful weather,-a period, with scarcely a break, of calm seas and almost cloudless skies. Under the influence of the great heat the temperature of the Channel waters rose continuously, until in August it had attained a point unprecedented for quarter of a century ; and it was of the highest interest to observe the effect of this high temperature, and of the prolonged calmness of the sea, upon the floating population of the neighbouring portion of the Channel. Numbers of semi-oceanic forms which rarely reach our shores arrived in remarkable profusion. In June the tow-nets were crowded with Salps, while towards the latter end of August they were almost choked by masses of living Radiolaria.

Even the bottom fauna was influenced, as was shown by the extraordinary abundance in the Sound thoughout the spring and 
summer of the Tectibranch Philine aperta. Oscanius membranaceus also, though to a less extent, was unusually plentiful, penetrating even some distance up the Hamoaze.

Another phenomenon which is probable referable to the same cause, although in a somewhat different manner, is the relatively greater abundance this year (1894) of many of the regular constituents of the bottom fauna. For example, the Hydroids Tubularia indivisa and a smaller form which appears to be Tubularia humilis, together with Coryne pusilla and Eudendrium ramosum, have been taken in the Sound this year in unusual quantity. The same remark applies to many Nudibranchs, and especially to the Alid Facelina coronata,* which has been remarkably common this year at Plymouth. I do not doubt that the unusual abundance of these and other forms may be directly attributed to the very favorable physical conditions under which the reproduction of their species took place in the preceding year. The destruction of larval life by physical agencies must then have been considerably less than the normal rate. Indeed, in the case of the oyster, as was attested by Prof. Herdman in a letter to Nature (July, 1893, p. 269), there was undoubtedly an unusually heavy fall of spat on the west coast of France last year, which implies that an unusually large percentage of larvæ were enabled to attach themselves and to pass safely through the critical stages of their metamorphosis ; and also, perhaps, that the reproductive activities themselves were rather above the normal.

So much for the general aspects of the fauna during the past eighteen months. Additional facts bearing out the above remarks may be gathered from the body of this paper.

In the three succeeding sections are given-firstly, a list of the principal captures and additions to the fauna made since my last $\dagger$ communication to this journal up to May 30th, 1894, when I left Plymouth; secondly, some observations on the breeding seasons of marine animals at Plymouth; and thirdly, some remarks on the periodic changes in the constitution of the floating fauna.

In several respects, however, I have to regret the incompleteness of my notes. They are compiled directly from my diaries, and are written on foreign soil, where I am without access to some of the appropriate works of reference and to several of my manuscripts. On this account the last two sections especially of this paper are offered simply as preliminary communications upon the interesting

\footnotetext{
* I showed some years ago that the smaller Nudibranchs are annuals, and require only a year to attain their full growth. The same thing is true of Hydroids and many other Invertebrates (this Journal, 1890, p. 450).

+ Notes on the Marine Invertebrate Fauna of Plymouth for 1892, vol. ii, 1892, pp. 333 to 339 .
} 
subjects of which they treat; I shall endeavour to expand them both in scope and detail when further observations have been made and the time is ripe.

RoscoFf ; June $30 t h, 1894$.

\section{FaUnistic Records.}

Hydrozos.-Several additional colonies of Tubiclava cornucopiæ have been obtained in 15 to 25 fathoms of water south of the Mewstone. In all cases they were growing, like our first specimen, on shells of Aporrhaïs or Turritella, tenanted by the Gephyrean Phoscolion strombi. Some of the colonies were young, and possessed a reticulate stolon, like Norman's original specimens from the Shetlands-thus confirming my anticipation that the solid carpetlike base of large colonies is not a specific difference, but a senile character (Trans. Devon. Assoc., 1892, pp. 378-9).

Clava cornea (of Hincks) is abundant on the fronds of Fucus growing in that branch of the Hamoaze known as the Lynher, or St. German's River.

In tide-pools under the Hoe two species of Clava are common, one being $C$. multicornis, and the other a larger and stouter form, which seems to be the Clava leptostyla of Hincks's monograph. To prevent confusion, however-since one of the characteristics of our form, at any rate, the purple colour of the gonophores, is nowhere mentioned, -I give its leading features here.-Colonies clustered, attached to stems of algæ and to the floor of limestone pools; polyps very large and stout, tall when extended, of a rich salmon-flesh colour; digestive cavity having a distinctly spiral marking, or even coiled appearance, which is seen when the polyps are fully extended as well as when contracted; gonophores in two, three, four, or rarely five large compact round bunches immediately beneath the tentacles, and of a conspicuous purple colour when mature.

Tubularia indivisa has been dredged occasionally in Millbay Channel. Good colonies were obtained there on April 13th, 1894, but the gonophores were provided with very short stalks, and did not form pendulous racemes. With them were large colonies also of Tubularia larynx, crowded with gonophores. On March 9th a small colony of a Tubularia was dredged in Barn Pool, growing on some Ceramium or Polysiphonia attached to a root of Laminaria. The stems were without annuli, the tentacles were white, and there was a collar-like expansion below the hydranths, and I inferred the species to be the T. humilis of Hincks's monograph. On the 19th, however, I collected some other colonies from tide-pools below the Hoe, and they resembled the preceding in almost all points except 
in the absence of a collar. The polypites were white, the stems entirely destitute of annulations or corrugations, and white. The colonies were crowded with gonophores, which each exhibited a red patch. I scarcely doubt that these two forms belong to the same species.

Coryne pusilla has been common in tide-pools below the Hoe, side by side with Clava multicornis and Tubularia humilis; also on the breakwater, and at Cremyll below the garden battery. Intermediate varieties between the Coryne pusilla and $C$. fruticosa of Hincks are common. On July 17th, 1893, I found an extensive colony of another Coryne attached to a root of Laminaria trawled in the Sound. The stems were slender, branched, and irregularly annulated; the polyps red, much elongated, and provided with fifteen to eighteen tentacles, scattered or irregularly whorled. The colony attained a maximum height of $1 \frac{1}{2}$ inches, but was for the most part less than this, and of lax growth. It is undoubtedly allied to Hincks's C. vermicularis, and I record it as such; but it should be noted that the colony was certainly not dense, and the tentacles were apparently less numerous than in Hincks's type. As our colony was without gonophores, however, it is possible that these differences may have been due to immaturity.

Eudendrium ramosum has been frequently dredged on the New Grounds and in Millbay Channel.

Gavveia nutans was dredged in Millbay Channel several times during April and May, 1894. It is interesting to notice that while this species is common between tide-marks at Hilbre Island at the mouth of the Dee, at Plymouth it is rare, and lives in deep water only (15 to 20 fathoms).

Another Gymnoblast which I found plentiful on certain stones at Cremyll presents several remarkable features which will justify a separate description: it is now under examination.

During the latter half of February and March, 1893, the tow-nets contained numerous specimens of the Anthomedusa Rathkea octopunctata, which is the Lizzia octopunctata of Forbes' "Naked-eyed Medusæ," and the Cytæis octopunctata of M. Sars. Haeckel has made a mistake in treating these as different forms, and in assigning them to different genera, viz. to Margellium and Rathkea respectively. In Haeckel's system (System der Medusen, pp. 95 and 97) each of these types possesses eight bundles of tentacles, but in Rathkea the bundles are perfectly similar to one another, while in Margellium the four perradial bundles contain a greater number of tentacles than the four interradial. The mature Rathkea (=Cytæis) octopunctata of Sars and Haeckel is characterised by having three tentacles to each bundle; but since Sars has shown that the inter- 
radials develop later than the perradials, and that the lateral tentacles of each bundle develop later than the median tentacle, a stage is consequently passed through in which the perradial bundles consist of three tentacles and the interradials of only one. On the other hand, Margellium octopunctatum is defined by Haeckel as possessing perradial bundles of three tentacles and interradials of two tentacles-apparently on the sole basis of Forbes' figure (loc. cit., pl. xii, fig. 3). In this definition Haeckel has disregarded Forbes' statement that the number of tentacles in the interradial bundles is "either two or three, . . . the number varying in different specimens" (loc. cit., p. 65), and I am able to confirm Forbes fully in this respect. The development of the lateral tentacles in the interradial bundles takes place very irregularly. In some instances I have seen them arising together, one on each side of the median tentacle, and growing at a uniform rate; but in the majority of cases there is an irregularity in the time of their origin, and one of the lateral tentacles may have become considerably developed before the rudiment of the other has appeared. It thus very often happens that individuals may be seen to possess interradial bundles of two tentacles only, and it is this condition which Forbes has figured. It is, however, as I have just shown, simply an instance of temporary asymmetry due to inequality of growth. The species Margellium octopunctatum of Haeckel has consequently no existence. The oral tentacles (Mundgriffel) of our own specimens show a single bifurcation only (cf. Giard, Bull. Sci. France et Belgique, xix, 1888, pp. 317, 318, pl. xxi), whereas Haeckel gives "Mundgriffel 3-4 mal dichotomisch getheilt" as one of the characteristics of his species,-upon what grounds I do not know. The buds, so characteristic of this medusa, form a longitudinal row on each of the four sides of the manubrium, each row containing from two to four buds, which increase regularly in size from the oral to the umbrellar region of the manubrium. I have not detected the spiral arrangement attested by Giard, although his remarks on the order of their development apply equally well to the specimens I have examined. The medusa was taken in the tow-nets in February and March of this year also, but not in the same abundance as last year. It was succeeded towards the end of April by other Margelid medusæ, Bougainvillea (Margelis), both principis and ramosa of Haeckel, which seem, indeed, to form only one species.

Other Anthomedusæ that have been taken are Corymorpha nutans, which was abundant in May this year ; Sarsia prolifera and tubulosa (rarely), Podocoryne (Dysmorphosa) carnea, Tiara octona, Amphinema Titania (= Saphenia dinema of Forbes), and Amphicodon amphipleurus of Haeckel. The last-mentioned very remarkable medusa 
had numerous buds arising from the tentacle bundle; it was taken on a few occasions only during April of this year.

Among Calyptoblastic Hydroids, I may record that Diphasia rosacea is common on stones in Millbay Channel.

The Campanularian medusæ offer great difficulties in the way of satisfactory identification, owing to our ignorance of the limits of growth and modification of which so many of the medusæ are capable after liberation; I will therefore content myself with descriptions in several cases. Several specimens of a large, delicate, and perfectly transparent medusa were dipped up from the boat's side on October 6th, 1892, which I found, upon examination, to be the Irene pellucida of Will, redescribed by Claus in the Arbeiten des Zoologisches Inst. zu Wien, iv. This medusa is the Geryonopsis pellucida of Forbes' monograph (p. 40), but is altogether distinct from the species described by Haeckel under the name Irene pellucida. The umbrella was depressed and broad, $2.4 \mathrm{~cm}$. in diameter. The gonads extended $8 \mathrm{~mm}$. from the edge of the umbrella, $i$. e. only two thirds of the radius. There was a distinct peduncle (Magenstiel), conical in form, $5 \mathrm{~mm}$. long. The oral lips, four in number, were produced and fimbriated. The tentacles, sixty-four in number, were very regularly disposed $(4+$ $4+8+16+32)$. The primary and secondary tentacles were as long as or longer than the oral lips, and the tentacles of the remaining orders diminished regularly in size and length according to their respective orders. Each tentacle consisted of a basal bulb and a terminal filament, often coiled. There was no trace, however, of true "spiral cirri." In addition there was also a variable number of tentacle rudiments, devoid of filaments, in positions which indicated the commencing formation of a sixth order of tentacles, sixty-four in number. Otolithic vesicles were present, usually one between every two adjacent tentacles, never more. Every tentacle was provided with an excretory pore, opening into the umbrellar cavity at the tip of a tubercle placed just above the velum. The species differs from the Irene pellucida and Irene viridula of Haeckel's monograph in the absence of spiral cirri. From the former it also differs in the fimbriation of the oral lips, in the absence of a conspicuous constriction between peduncle and stomach, in the regularity of the tentacles, and in the distal position of the gonads on the radial canals. From the Geryonopsis delicatula of Forbes it differs in the regularity of the tentacles, in the absence of a conspicuous contraction of the peduncle, and in the smaller size of the oral lips and of the velum.

In addition to Laodice cruciata (= Thaumantias pilosella of Forbes and the "Irene viridula" of Mr. Bles's Notes on the Plankton of Plymouth, this Journal, II, 1892, p. 342), which is common at Plymouth every summer, numbers of an Irene-like Phialid were taken 
in the tow-nets during August, 1893. The tentacles were regular, and sixteen in number. One or generally two otocysts were situated between every two adjacent tentacles. There were no cirri. The mouth had four very short lips, absolutely smooth; and there was no peduncle. The gonads formed four oval swellings almost at the distal extremities of the four radial canals.

Early in February this year I again saw a number of Leptomedusæ resembling those just described in many respects, but approaching more nearly Haeckel's Phialidium variabile. The size was in some cases as much as that of a threepenny piece. The tentacles, sixteen in number, were long, and arose from stout pigmented bulbs. There was one otocyst between every two adjacent tentacles, and in one instance I saw two in that position. No peduncle. Radial canals four; gonads oval, elongated, in the distal halves. The species at first suggested to me the Epenthesis cymbaloidea of Haeckel, but the occasional occurrence of two otocysts in an intertentacular are, the absence of a distinct ocellus, and the sharp boundary between the basis and filament of the tentacles, eventually inclined me towards Phialidium variabile.

Another Leptomedusa which it may be useful to record is the Thaumantias octona of Forbes, which I observed on two occasions in February and March, 1894. Haeckel places this medusa in the genus Eucope, owing to his belief that the "two vesicles" which Forbes describes and figures in juxtaposition on the edge of the umbrella are the optical expression of an otolithic capsule. These bodies, however, are quite separate from one another, as described by Forbes; and although I am not able to throw any light on their function or fate, I may say that Haeckel's suggestion is devoid of foundation.

The interesting Lucernarian Depastrum cyathiforme was twice obtained last year, in March at Drake's Island, and in May at Rame Head. One of the specimens obtained at the latter place exhibited a distinct lateral bud, a phenomenon not hitherto recorded, I believe, among Lucernarians.

Ctenophora. - A number of specimens of the lobate Ctenophore Bolina hydatina were obtained on several occasions in the Sound during the latter half of May this year. Many of the specimens were of the full size mentioned by Chun in his monograph, viz. up to $4 \mathrm{~cm}$. in length, and were obtained in capital condition in spite of their extreme delicacy. The species was first identified at Plymouth by Mr. Riches, who noticed specimens in the tow-nets towards the end of May, 1892. Its recurrence at exactly the same period this year renders all the more remarkable its apparent absence from Plymouth during the intermediate year, especially when the calmness and warmth of that summer are taken into consideration, 
AnthozoA.-During May, both in 1893 and 1894, the Leptomedusæ which then abounded in the Sound, and which seemed to be in part the young stages of Irene pellucida, and in part Phialidium variabile, were infested to a large extent with parasitic Actinian larvæ, which I had little doubt (after external examination only, however) were the young stages of Halcampa chrysanthellum.

In my notes on the fauna for 1892 (Journal, 1892, p. 334) I recorded Bunodes coronata as occurring at Plymouth. This is perfectly true, but the species which I intended at the time to record was Bunodes verrucosa (= gemmacea of Gosse). Chitonactis coronata (the Bunodes coronata of Gosse) has been taken on many occasions in the deeper water outside the Breakwater, as well as once or twice in the deep water of Millbay Channel. I have no doubt that those who are familiar with the recent changes and present state of Actinian nomenclature will forgive my momentary confusion of names, which I now correct.

In my former list I omitted to mention that Epizoanthus incrustatus* is common at Plymouth on a patch of ground a short distance south of the Mewstone, where it covers the shells tenanted by Anapagurus lævis. Another species of Zoanthid, Epizoanthus couchii, which is common in the Sound around the Duke Rock, and to a less extent in Millbay Channel, in which localities it may be found forming linear or retiform colonies over stones and shells.

Turbellaria.-Mr. Gamble identified as Fecampia erythrocephala (Giard) a remarkable Rhabdocœle which he found infesting a large percentage of young shore-crabs (Carcinus mænas) in the summer of 1893. I had seen a few specimens previously in basins in which some coralline from tide-pools had been placed ; they must have just emerged from the crabs in the coralline. The curious cocoons formed by Fecampia are also very plentiful on stones at Plymouth, both on the shore and down to a depth of 5 or 6 fathoms.

Снеторода. - I am unable to refer to Miss Buchanan's preliminary report on the Polychæta of Plymouth (Brit. Assoc., 1892), but at the risk of repetition will record here a few species which I believe are not mentioned in her list. A single mutilated specimen of Maldane cristagalli of Claparède was dredged on a patch of ground, consisting of hard rock and intervals of sand, a short distance south of the Breakwater Fort on December 14th, 1892. It was associated with specimens of Glycera capitata and Eunice Harassii. The former, however, lives at Plymouth wherever there is abundance of clean coarse shell sand, and Eunice Harassii is not uncommon in Millbay Channel and around the Duke Rock, where it lives in holes of stones.

* The nomenclature of Haddon's Revision of British Actiniæ (Trans. Roy. Dublin Soc.. vol. iv, 1891) is here followed.

NEW SERIES.-VOL. III, NO. III. 
It is also sometimes taken on the shore. The much larger Eunicid, Marphysa sanguinea, is common both in Rum Bay and at Drake's Island. It inhabits deep crevices of the rocks, and can only be obtained by breaking the latter to pieces by means of a crowbar.

On January 26th, 1893, I noticed among a number of Phyllodoce maculata, which emerged from material dredged off the west shore of Drake's Island, two specimens of a charming white Phyllodoce with reddish eyes, which I was not able to identify. Each segment except the most anterior ones was provided with a girdle of cilia. The parapodial lamellæ were fan-shaped, and each was marked with a brown, or rather a fawn-coloured spot. The inferior edge of each lamella was also provided with large vibratile cilia. The back of the worm was faintly pigmented with fawn-colour. The small but handsomely marked Syllid, Proceræa picta of Ehlers, is fairly common among the stones dredged in Millbay Channel. A species of Myrianida ${ }^{*}$ is constantly recurring at Plymouth, one or two specimens at a time. I believe it is identical with the Myrianida maculata of Claparède, though I cannot at present say whether it is different from the Myrianida pinnigera of Montagu, whose original description I have not seen. It is easily recognised by its colour, which is white, with deep orange-red blotches on the back of every third or fourth segment. It is fairly frequent among the roots of Laminaria. On one occasion (May 29th, 1893) I found a specimen under a stone at the Breakwater, which was provided with a chain of buds, some of which had detached themselves before my return to the laboratory. Amblyosyllis (Gattiola) spectabilis, I find, is a spongicolous form, and can often be obtained in quantity by tearing open the larger sponges, of Desmacidon-like texture, dredged in Millbay Channel. A large eyeless Polydora (? flava, Claparède) is common in Rum Bay, and at Rat Island in St. German's River, where it constructs mud burrows between the layers of shaly rock. In February I have found many of these burrows also containing a long segmented gelatinous egg-string, almost as long as the worm itself $(i . e$. about two inches), lying flat and straight in the burrows. The worm itself possesses a bifid præoral lobe, and the branchiæ commence on the eighth segment ( $i$. $e$. the third after the apodous segment). The dorsal blood-vessel is conspicuous, the blood being crimson. At Rat Island I have also taken specimens of Scoloplos armiger, living, like the Polydora, in the mud between layers of shale, and also in the dirty sand around. In November, 1892, a single specimen of the

* Good figures of this species are given by Malaquin (Mem. Soc. des Science et des Arts, Lille, 1893, p. 287, pl. i), who identifies the Myrianida maculata of Claparède with the $\boldsymbol{M}$. fasciata of Milne-Edwards. 
remarkable Ammotrypane aulogastra of Rathke (non Johnston) was dredged off the Duke Rock.

Two specimens of the pelagic post-larval stage of Arenicola (described in this Journal, III, 1893, p. 48, by Dr. Benham) were again obtained this year in February, but about a fortnight earlier than in 1893.

GePhyrea.-Phoronis hippocrepia has been frequently dredged, especially in Millbay Channel, and I have also taken it on the shore at Cremyll.

Mollusca.-Several specimens of Lima Loscombii have been taken alive in about 20 fathoms off Stoke Point and south of the Mewstone. Large specimens of Arca tetragona can be obtained in Rum Bay by breaking the rocks there to pieces with a crowbar. They live in deep holes and crevices of the rocks, to which they are permanently attached by their stout operculum-like byssus. In the majority of cases the shells are remarkably abraded and polished by the efforts of the molluses to enlarge the crevices in which they are fixed, so as to make room for their own increasing size. Not only is their layer of bristles entirely worn away in many cases by this friction of the valves against the surrounding rock, but the rock itself is rubbed away and polished by the incessant friction. In many cases I found the rock to be an almost perfect mould around the mollusc, while the aperture to the crevice by which the larval or young Arca had originally entered was not large enough to admit a specimen of even half the bulk to which the mollusc had attained!

A remarkably elongated specimen of Loligo media was trawled on April 14th, 1893, eight miles south of the breakwater. I took the following notes of its dimensions :

Maximum length of mantle . . . $136 \mathrm{~mm}$. " breadth of fin . . . 27 ,

Anterior extremity of fin to apex of body . 98 ,"

Posterior , " " . 43 ,

The extraordinary abundance of the Tectibranch Philine aperta during 1893 has been already mentioned. Hundreds of specimens could easily be obtained at any time in the eastern portion of the Sound, and the species with its gelatinous egg-masses was so abundant in July as to choke the meshes of the shrimp-trawl when worked in Jennycliff Bay. Oscanius membranaceus also, though not so abundant as Philine, was unusually plentiful, especially in Millbay Channel and the Hamoaze.

In February of this year I found a single specimen of an apparently undescribed $*$ type of Tectibranchiate mollusc which unites in

* This is the Colpodaspis pusilla of Michael Sars, a very rare and interesting form, of which only two specimens have previously been obtained. 
a remarkable manner the most salient characters of the Notaspidea and Cephalaspidea. I have prepared figures of this little animal, a description of which will be published immediately.

Several rare Nudibranchs have been taken, chief of which are the Aolid Berghia coerulescens and Hero formosa. Both forms inhabit the deeper waters outside the Breakwater, and the latter is by no means uncommon. Additional captures have also been often taken of Aolidiella glauca and Platydoris planata, and, less frequently, of Amphorina coerulea, Antiopa hyalina, Embletonia pulchra, Hermæa bifida, and Thecacera pennigera. The specific habits of most of these forms are still unknown, but in the case of two Dorids, Rostanga coccinea and Lamellidoris oblonga, the following observations upon their habits may be useful. Just as Jorunna Johnstoni* lives among small Halichondrix, upon which it feeds, and which it strikingly mimics in general and even detailed appearance, so I have found that Rostanga coccinea, which is of a bright scarlet colour, lives-in both senses-upon red encrusting sponges. This species, which formerly seemed to be rare at Plymouth, I have been able to obtain easily by dredging or collecting in those places where its food-sponges are abundant. On the other hand, Lamellidoris oblonga lives not upon sponges, but upon Polyzoa of the genus Cellaria, especially the stouter species, the twigs of which it clasps firmly with its foot. This Dorid is not well described by Alder and Hancock, no doubt from their lack of a sufficient number of specimens from which to educe the characteristic features. The back normally shows a variable number of irregular, ring-like, dark spots (of which there are usually eight or nine more conspicuous than the rest), and round the entire periphery of the back there is a pigmented border, which has no sharply defined edges, but is a marked feature when a number of specimens are examined and compared. The edges of the rhinophoral fossæ are raised into a slight rim or sheath provided with three tubercles. The chief differences between individuals for the most part concern simply the relative intensity of the brown pigmentation : the annular spots and border were indistinguishable in only three out of forty specimens. I first noticed this species on December 19th, 1892, when scores of specimens were taken from Cellaria trawled seven miles south of the Breakwater. With them were associated a few specimens of Lamellidoris pusilla and Lamellidoris proxima.

Another small Dorid, whose back is strikingly marked by conspicuous purple tubercles upon a field of yellow, seems to be new to science, and will be described elsewhere.

* Garstang, Notes on the Structure and Habits of Jorunna Johnstoni, Conchologist, vol. ii, 1892. 
In November, 1892, among coralline from tide-pools, I repeatedly found specimens of a minute white Dorid, whose back exhibited a regularly arranged series of very spiny tubercles. I was completely at a loss as to its identification, until towards the end of the month several slightly larger specimens were taken, which showed traces of pigmentation,--brownish patches here and there, and a brown ring on each rhinophore. During the next month or two I followed out the growth of these little Nudibranchs by obtaining fresh specimens from the tide-pools from time to time, until I had a complete series between the minute and absolutely white form and the fully developed and highly pigmented Afgirus punctilucens. From these observations I am strongly inclined to regard the Algirus hispidus of Hesse as merely one of the younger stages of Agirus punctilucens. They also enable me to identify, as a still earlier stage of the same species, a remarkable post-larval form which had occurred in the autumn tow-nettings, as observed both by $\mathrm{Mr}$. Bles at Plymouth and Mr. Vallentin at Falmouth. It was simply one of these minute white Aggirus with the addition of a pair of large velar lobes, by means of which it swam freely in the water.

Two other Gastropod larvæ that I have noticed in the tow-nettings are worthy of record. One is the Echinospira diaphana, figured in Bronn's Thier-Reichs, and the other the Cirropteron semilunare of Michael Sars (Besk. og Jagttag., \&c., Bergen, 1835). In each of these forms the velum is produced into ciliated lobes, three on each side in Echinospira, and two in Cirropteron. The former occurs in the summer tow-nettings every year; the latter I have only seen once, towards the latter end of August, 1893.

Crustacea.-To my former record of Apseudes talpa I may add here the occurrence of Apseudes Latreillii at Plymouth. I found numerous specimens in the mud around the roots of corallines from Drake's Island in July, 1893, and on other occasions.

In addition to the Schizopoda mentioned in my previous Notes, I have taken the following also at Plymouth:-Siriella frontalis (M. Edw.), Drake's Island, among weeds, June 2nd, 1893, one specimen. Siriella jaltensis, which occurred in the tow-nets at night in September, 1892, abundant on the shore at Drake's Island among weeds, June 2nd, 1893. Heteromysis formosa (S. I. Smith), a few at a time only, Millbay Channel, New Grounds, Cawsand Bay, Yealm, and off Stoke Point. Leptomysis mediterranea, common in Cawsand Bay, June 5th, 1893. Leptomysis gracilis, October, 1893. Erythrops elegans, October, 1892 and 1893. Mysidopsis gibbosa, Cawsand Bay, several occasions. Hemimysis Lamornæ, Cawsand Bay, July 5th, 1893. Macromysis inermis and M. neglecta, among weeds everywhere. Schistomysis arenosa, Cawsand Bay, Whitsand Bay. 
The form " allied to S. arenosa," referred to in my previous Notes, is this species, as Canon Norman, who kindly examined some specimens, has assured me.

Nite edulis has been trawled in the Sound occasionally, but is rare.

Pirimela denticulata is not uncommon in the patches of clean coarse shelly gravel to the south of Drake's Island. Its highly speckled appearance renders it very inconspicuous on this ground, into which, however, it promptly burrows so as to be completely hidden from view.

Stenorhynchus egyptius (M. Edw.) is not uncommon on weedy ground, and is at once distinguishable from the other spider-crabs by its stripes of reddish-brown pigment. The habit of decking the body and limbs with bits of seaweed is as marked in this species as in any of the others, and as it generally lives among reddish weeds its own coloration contributes greatly to its disguise.

Echinoderma.-During August, 1893, the tow-nets frequently contained one or two specimens of the interesting type of Bipinnaria larva described by me in the Quart. Journ. Micr. Sci., January, 1894.

Tunicata.-During August and September, 1893, a considerable number of specimens of a small Doliolum were found in the townettings. They agree with Herdman's Doliolum tritonis in all respects except that the stigmata begin dorsally close behind the second muscle band,-a point of no great importance. When alive these little creatures are perfectly transparent, and dart about with great activity in the water.

Earlier in the year-from the middle of June to the end of the first week in July - the Sound was visited by large shoals of the Salp Thalia democratica-mucronata. Many of the specimens first taken were of the sterile or nurse generation, and were provided with young chains ; the later specimens, on the other hand, were chiefly sexual forms derived from the breaking up of the chains, and a large number of these contained embryos - one only to each adult-in different stages of development.

\section{Notes on the Breeding Seasons of Marine Animals at Plymodth.}

These notes are founded almost entirely on my own observations, and are necessarily incomplete, though, I believe, not inaccurate. My original intention was to continue such observations for at least another year before publication, in order to be able to present a fairly complete record; but my departure from Plymouth has interfered with this plan, and, at the request of several friends, I publish 
my notes as they are. They will serve, I hope, as at least an indication of the breeding periods of many forms at Plymouth. A more extensive list, including the records given in various monographs and original memoirs, for the whole of the British Isles, is at present under preparation, and will be presented for publication at no distant date.

\section{Protozoa.}

Noctiluca miliaris._-(Swarm-spores) March (S. F. Harmer).

\section{Porifera.}

Principally July, August, September.

\section{HydrozoA.}

In those Hydroidea which possess sessile gonophores or sporosacs the breeding season may be regarded as practically coincident with the period of gonophore-formation, although actually a little later; but in the case of those Hydroids which attain maturity in the form of free medusæ, the time that may elapse between the separation of the medusæ and the deposition of ova is in the majority of cases still unknown, and is certainly not a constant quantity. The periods given here will therefore be the periods of gonophore- or sporosac-formation. The breeding seasons of free medusæ may be regarded as the periods when they attain their full growth and greatest abundance-information upon which points may be gathered from the third section, dealing with the floating fauna.

Tubularia indivisa.-February, March, April.

Tubularia larynx.-April.

Tubularia bellis.-April.

Tubularia humilis.-March.

Myriothela phrygia.-May to August (Bourne).

Clava multicornis.-March, April.

Clava leptostyla.-March.

Clava cornea.-February (Bourne), May.

Tubiclava cornucopiæ.-May, June.

Hydractinia echinata.-August.

Perigonimus repens.-August.

Podocoryne carnea.-August (and earlier).

Coryne pusilla.-May ; July (Bourne).

Coryne vaginata.-May to August (Bourne).

Syncoryne eximia.-May (Bourne).

Eudendrium ramosum.-February, March.

Eudendrium capillare.-May, September.

Garveia nutans.-April.

Obelia geniculata.-March, September. 
Gonothyræa Loveni.-April, October, November (sparsely).

Sertularia argentea.-February.

Sertularia pumila.-March, April, May, June, July.

Diphasia pinnata.-April.

Diphasia rosacea.-April.

Sertularella Gayi.-February, August, September, October.

Hydrallmania falcata.-January.

Halecium Beanii or halecinum.-January to July.

Plumularia setacea.-February to June.

Plumularia pinnata.-April.

Antennularia antennina.-May, June, July.

Antennularia ramosa.-May.

Aglaophenia pluma.-August.

Aglaophenia myriophyllum.-August.

Aglaophenia tubulifera.-October.

SiphoNopHoRA.

Muggiæa atlantica.-August, September (J. T. Cunningham ; E. J. Bles).

ScyphozOA.

Aurelia aurita.-(Strobilising) February, (breeding) June, July.

ANTHOZOA.

Alcyonium digitatum.-November, December, January.

Actinia equina.-January onwards (to August?).

Bunodes verrucosa (gemmacea).-April, September.

Urticina felina (Tealia crassicornis).-May.

Ohitonactis coronata.-January to April.

Cereus pedunculatus (Sagartia bellis).-December, January,

February.

\section{Turbellaria.}

Fecampia erythrocephala.-August, September.

Leptoplana tremellaris.-August (F. W. Gamble).

Eurylepta cornuta.-August (Gamble).

Stylostomum variabile.-August (Gamble).

Cycloporus papillosus.-August (Gamble).

Nemertina (cf. Riches, Journ. M. B. A., III, 1893, p. 5).

Cephalothrix bioculata.-April, June.

Cephalothrix linearis.-March.

Amphiporus lactifloreus.-March.

Amphiporus pulcher.-September.

Amphiporus dissimulans.-March, September, October.

Tetrastemma dorsale.-September, October, November. 
Tetrastemma candidum.-September, October, November.

Tetrastemma vermiculatum.-September, October, November.

Nemertes Neesii.-March to October.

Lineus obscurus (= gesserensis).-January, February.

Archiannelida.

Dinophilus tæniatus.-April (Harmer).

Histriobdella Homari.-September (E. J. Allen).

СнжтороDA.

Ophryotrocha puerilis.-August.

Nereis fucata.-May.

Phyllodoce maculata.-January, February.

Hesione (= Psamathe), sp.-August.

Scoloplos armiger (?).-February.

Polydora (flava ?).-February.

Sabellaria spinulosa.-May.

Serpulidx.-June.

Terebellidæ.-May.

Polycirrus aurantiacus.-July.

Cirratulus cirratus.-February (and earlier).

Hirudinea.

Pontobdella, sp.-August (advanced embryos only).

Polyzoa.

Crisia ramosa.-July.

Flustrella hispida.-March.

Smittia, sp.-March (Harmer).

Mollusca.

Amphineura.

Chiton, sp.-March.

Gastropoda.

Littorina littorea.-February.

Littorina littoralis.-February.

Littorina rudis.-June.

Capulus hungaricus.-January, February, March.

Buccinum undatum.-January, February, March, April.

Purpura lapillus.-January, February, March, April, November.

Murex erinaceus.-May (and earlier).

Nassa reticulata.-February, March, April, July, September.

Nassa incrassata.-April, June, August, September.

Lamellaria perspicua.-January to May. 
Aplysia punctata.-June to October.

Philine aperta.-May, June, July.

Elysia viridis.-October (and earlier ?).

Hermæa dendritica.-June.

Aolis papillosa.-March, April, May, June.

Eolidiella Alderi-August.

Favorinus albus.-November.

Facelina coronata.-April, May.

Galvina Farrani.-May, October.

Galvina exigua.-March.

Galvina cingulata.-July.

Tergipes despectus.-March.

Doto fragilis.-January.

Doto coronata.-April.

Candiella (Tritonia) plebeia.-November.

Hero formosa.-April.

Doris tuberculata.-January to June.

Acanthodoris pilosa.-January, February.

Lamellidoris bilamellata.-November (?).

Lamellidoris oblonga.-April.

Lamellidoris pusilla.-February.

Goniodoris nodosa.-December, January to May, September.

Goniodoris castanea.-February, May, July, September.

Polycera quadrilineata.-July, August.

\section{Lamellibranchia.}

Arca tetragona.-July.

Teredo navalis.-May.

Cephalopoda.

Eledone cirrosa.-April, May.

Sepiola atlantica.-July, August.

Loligo media.-April, May, June, October (late embryos).

Loligo Forbesii.-April to September.

\section{Crustacea.}

\section{Cladocera.}

Podon (intermedius, Lilljeborg ?).-March, April, June (?).

Evadne Nordmanni.-March (scarce), Julý, August, September.

Winter ova in September and October (E. J. Bles).

\section{Copepoda.}

Some forms or other may be found breeding at almost any time of the year. 
Cirrhipedia.

Chthamalus stellatus.-January, February, March, August, September.

Sacculina carcini.-May, June, July, August, September.

Leptostraca.

Nebalia bipes.-April, May, June, July (late embryos).

\section{Edriophthalmata.}

The great majority breed between April and August.

\section{Cumacea.}

Pseudocuma cercaria.-May, June.

Schizopoda.

Siriella jaltensis.-June.

Gastrosaccus sanctus.-August.

Gastrosaccus Normani.-September.

Heteromysis formosa.-October, November.

Erythrops elegans.-October (late embryos only).

Mysidopsis gibbosa.-July.

Leptomysis mediterraneæ.-June.

Macromysis flexuosa.-April, May, June, July.

Macromysis inermis.-June.

Schistomysis arenosa.-June.

Schistomysis spiritus.-June, July, August (late stages only).

\section{Decapoda.}

Homarus vulgaris.-August, September. Larvæ hatched in May and June.

Palinurus vulgaris.-Larvæ hatched in July (Cunningham).

Palæmon serratus.-November, December, January to June.

Palæmon squilla.-July (and earlier).

Palæmonetes vulgaris.-May, June, July, August (late stages only).

Pandalus annulicornis.-November, December, January, February.

Pandalus brevirostris.-April.

Hippolyte Cranchii.-April, May.

Virbius varians.-May, June, July.

Nika edulis.-May.

Crangon vulgaris.-December, January to August.

Crangon fasciatus.-May. 
Crangon sculptus.-June. Crangon trispinosus.-July. Diogenes varians.-July. Eupagurus Bernhardus.-April.

Eupagurus Prideanxii.-March, April, May, June, July. Anapagurus lævis.-April, May. Galathea squamifera.-April. Galathea dispersa.-March.

Galathea intermedia.-March.

Porcellana longicornis.-March, April, May, June, July.

Porcellana platycheles.-April, May, June, July.

Eurynome aspera.-January, February, March, April.

Stenorhynchus phalangium.-May.

Stenorhynchus tenuirostris.-May.

Hyas coarctatus.-August.

Carcinus mænas.-December, January to August.

Portunus depurator.-March to August.

Portunus holsatus.-March.

Portunus arcuatus.-March, April, May.

Portunus pusillus.-April.

Portunus marmoreus.-May.

Pilumnus hirtellus.-April, May, June.

Xantho floridus.-May, June.

Xantho rivulosus.-May, June.

Cancer pagurus.-February to ?.

Pantopoda.

Nymphon gracilis.-May.

Ammothea, sp.-August.

Echinoderma.

Asterias rubens.-May.

Asterina gibbosa.-May, June.

Ophiothrix (? pentaphyllum).-February.

Amphiura squamata.-May, June, July.

Echinus miliaris.-May.

Echinus acutus.-July.

Antedon rosacea.-Pentacrinoid larvæ in September and October.

Tunicata.

Oikopleura dioica.-March, April.

Thalia democratica-mucronata.-July.

Botrylloides rubrum.-August, September, October.

Botryllus violaceus.-June, July, August.

Styelopsis grossularia.-May, June, July, August, September. 
Ciona intestinalis.-September (and earlier?).

Clavelina lepadiformis.-June.

Archidistoma aggregatum.-June.

Morchellium argus.-September (and earlier ?).

Amaræcium Nordmanni.-June.

Prsces.

\section{Elasmobranchii.}

Scyllium catulus.-November, December, January.

Scyllium canicula.-December, January, February.

Acanthias vulgaris.-January, February, March.

\section{Teleostei.}

Chiefly between January and June.

\section{Materials for a Calendar of the Floating Fauna.}

The floating fauna of the sea in the immediate neighbourhood of land is so largely composed of larval or other forms derived from the bottom fauna, and possessing in the majority of cases only a transitory pelagic existence, that, from the very nature of the case, the floating fauna assumes a highly periodical character, whose phases are directly dependent on the seasons of breeding, hatching, and metamorphosis of the animals living on the adjacent or underlying tracts of submarine land. This fact alone invests the recording of such simple phenomena as the breeding seasons of marine animals, or their rates of growth and metamorphosis, with a high degree of interest and value; and in the days to come, when this fact has been sufficiently and practically appreciated, we shall make much more rapid progress in our knowledge of the bionomics of the sea. The dependence of the floating and the bottom faunas of our coasts upon each other is so intimate that it is impossible to separate the efficient study of the one from that of the other. A bottom-haunting species no sooner attains its breeding or its hatching period than the floating fauna immediately receives a new addition to its numbers. For a longer or shorter period the larvæ in question lead a pelagic life, and then, sooner or later, sink once more to the bottom to undergo their final transformations. Seeing that every species has its own particular breeding season, which does not necessarily coincide with that of any other species, and that the duration of the pelagic stage is equally variable in different cases, it follows that there must be a perpetual change going on in the constitution of the floating fauna in any one locality, an incessant rising to the surface of new forms just commencing their pelagic phase, 
and an incessant sinking to the bottom of surface larvæ whose floating period has come to an end. Were our work completed, our calendar of the floating fauna would largely coincide with, or bear a definite relation to, our calendar of the breeding seasons of bottomliving animals; but the insufficiency of present records, combined with their obvious want of mutual correspondence, shows what a large amount of observation and work remains to be done before the desired pitch of correspondence is attained.

The periodic character of the floating fauna is also manifested in other ways, and especially in certain seasonal changes which the gradual rise or fall of temperature during the year superinduces. These changes are due to actual immigrations of forms whose homes for the most part are in other regions, but which arrive at particular points upon our coasts when the temperature and other physical conditions admit of, and conduce to, their migration. The periodical changes which were first dealt with here were those of larval or metamorphic forms (e.g. most medusæ), whose derivation from the bottom fauna, and, in most cases, whose eventual return to it give rise to an incessant vertical interchange of material; but the forms which are especially concerned in these seasonal changes are for the most part creatures whose entire existence is pelagic $(e . g$. Siphonophores, Trachomedusæ, Copepods, Sagitta, Salpa), and which exhibit a merely horizontal translation from place to place according to the stress of physical conditions.

The situation of Plymouth at the head of a landlocked bay and at the western end of the English Channel renders the study of its floating fauna both difficult and interesting. This fauna is in fact not one fauna, but three faunas, - that of the harbour itself, which may be called the indigenous element; that of the adjacent coasts and of mid-Channel, which may be termed the tidal or Channel element; and that of the Atlantic, or the oceanic element. It is only by taking special precautions that one can isolate the first of these constituents from the other two, viz. by tow-netting within the Breakwater at low tide, when the wind has been light or northerly. At high water the Sound is naturally invaded by foreign forms carried inwards by the flood tide, and this may include eddies from the Channel tide properly so called; while protracted southerly or westerly winds inevitably produce an incursion of pelagic forms from the Channel or the ocean. A special study of the floating fauna would therefore take all these points into practical consideration, and I mention them here in order to warn those who may use these brief notes of the different factors of which the fauna at Plymouth consists, and of the impossibility, after the irregular experience of a few years only, of producing a calendar which shall in all points 
discriminate properly between the essential and the accidental phenomena observed.

Notwithstanding this consideration, however, and in spite of the incompleteness of my records, of which no one is more conscious than myself, I believe that I am in a position to offer a least the groundwork for the construction of such a calendar,* the completion of which would be an incalculable boon to the working naturalist, and lead to results of which one can dimly foresee the nature and importance.

January.-The tow-nettings in January are a trifle richer than those taken in December, but beyond that possess few positively distinctive features.

The alga Halosphæra viridis is usually present.

There is a marked scarcity of Cœlenterate life. The jars often seem to contain nothing but Copepods $†$ and a few Sagitta, which, however, are usually large at this time of the year.

The Invertebrate larval forms present are Cirrhipede Nauplii, Polychæte trochospheres and later larvæ, with a few veligers and Zоææ.

Teleostean ova and larvæ make their appearance and increase in numbers towards the end of the month. Herring larvæ (Clupea harengus) are now taken.

The fauna distinctly ameliorates towards the end of the month.

February.-The improvement, both quantitative and qualitative, of the floating fauna, which was noticeable towards the end of January, becomes marked this month.

Teleostean ova and larvæ are plentiful.

The sea swarms with Copepod and Cirrhipede Nauplii, with Polychæte larvæ (Polynoidæ, Phyllodocidæ), with Prosobranch, and especially Opisthobranch veligers, and with Decapod larvæ, both Mysis and Zoæa stages.

* Since my paper was written I have found that my idea of a calendar of the floating fauna is not new, and that a very full and valuable summary of the periodic changes in the pelagic fauna of St. Andrews was published by Prof. McIntosh in 1889 (Seventh Report, Scottish Fishery Board), part iii, pp. 259-301). The resemblances and differences between our records are of considerable interest.

+ It is easily observable that various species of Copepods are also periodic in their occurrence, but I do not refer to them in these notes, as I have not yet familiarised myself with the different forms and names. Reference should be made on this point to $\mathrm{Mr}$. G. C. Bourne's Report on the Copepoda of Plymouth, this Journal, vol. I, 1889, pp. 144152. It would appear from Mr. Bourne's report that Clausia elongata is characteristic of the three last and three first months of the year; Oithona spinifrons, Euterpe gracilis, and Corycrus anglicus of the spring (though the two latter species have been recorded for September by Mr. Bles); Paracelsus parvus of the summer; Temora longicornis of the early summer and autumn; Anomalocera Patersonii of the autumn. Cetochilus septentrionalis (= Calanus finmarchicus) and Dias longiremis were obtained throughout the year; but the former most abundantly in the autumn, the latter in the spring. 
Cœlenterates make their appearance. The ephyræ of Aurelia lead the way, and become increasingly abundant. Rathkea octopunctata represents the Anthomedusæ; and a medusa that appears to be the Phialidium variabile of Haeckel ushers in the Leptomedusæ. Minute Obelia medusæ become noticeable as the month progresses. Occasionally the Channel tide introduces the ova and larvæ of Ctenophores and errant specimens of the Siphonophore Muggiæa atlantica.

The Polyzoan larvæ Cyphonautes and the larvæ of Lamellibranchs are common; and the pelagic post-larval stage of Arenicola, in its gelatinous tube, may from time to time recur.

Echinoderm larvæ, especially Auricularia, are usually abundant during a portion of the month.

The Appendicularian Oikopleura dioica is often plentiful.

March.-Halosphæra is plentiful this month, and Rhizoselenia and Chrtoceros often become extremely abundant.

At the end of the month the gelatinous alga Tetraspora of Pouchet makes its appearance, first in the Channel and soon afterwards in the harbour.

Shoals of ephyræ of Aurelia may be taken in the first fortnight, showing a distinct increase in size since their first appearance; but towards the end of the month, during their metamorphosis into the medusa form, they begin to disappear and are difficult to discover.

Rathkea octopunctata is plentiful. The Anthomedusæ Sarsia prolifera (and tubulosa?) and Podocoryne (Dysmorphosa) carnea make their appearance; and the earlier phases of the Leptomedusæ Clytia Johnstoni and Irene pellucida (Claus, non Haeckel) are to be obtained, together with numbers of small Obelia and a few Thaumantias.

The Cereanthid larva Arachuactis appears, and is plentiful towards the end of the month.

Minute Planarians are sometimes noticeable.

The later stages of Phyllodoce larvæ are plentiful; the larvæ of Polydora also occur.

Crustacean larvæ of all kinds abound, and the Zoææ of Porcellana begin to appear.

The Cladocera Podon and, more scantily, Evadne arrive. Echinoderm larvæ (Auricularia, Bipinnaria, Pluteus) occur at times.

A striking feature of March tow-nettings is the profusion of the Appendicularian Oikopleura dioica, which is now breeding; its gelatinous houses (a mysterious scum to the unwary) are often a great nuisance, but a greater is to follow.

April.-Tetraspora abounds, discolouring the sea and choking the meshes of the nets in two or three minutes. Towards the end of the 
month these floating and troublesome algæ begin to be converted into so many gelatinous balls of motile spores.

The Diatoms Rhizoselenia and Coscinodiscus also abound, but Halosphæra disappears until the autumn.

Among Anthomedusæ, Rathkea disappears and Bougainvillea takes its place. Amphicodon amphipleurus may also occur. Among Leptomedusæ, small medusæ of Obelia and Clytia are numerous.

The later stages of Arachnactis are represented.

Larvæ of the Nemertine Cephalothrix may be found.

It is impossible to speak with much confidence, but there appears to be a rapid reduction during this month of the numbers of Neuplii and Polychæte larvæ.

Megalops larvæ become increasingly numerous. Large Portunid Zoææ make their appearance towards the end of the month.

Plutei are almost the only Echinoderm larvæ, and they do not seem to be plentiful.

May.-The formation of spores in Tetraspora proceeds apace, and leads to a rapid reduction in the numbers of the alga already noticeable early in May. Towards the end of the month the gelatinous alga has entirely disappeared.

The sea swarms with Craspedote medusæ, especially with those of the Campanularians, e.g. Obelia lucifera of fair size, Phialidium variabile (?), Thaumantias, and half-grown Irene pellucida. The most abundant Anthomedusa is Corymorpha nutans, but Amphinema Titania and Tiara octona also may occur.

Full-grown Ctenophores usually become numerous in the latter half of this month; Hormiphora plumosa always, and the magnificent lobate form Bolina hydatina in particular years.

Towards the end of the month Aurelia aurita begins to reappear in the form of young medusæ.

The parasitic larvæ of the Actinian Halcampa are plentiful on Campanularian medusæ.

The Polychæte larvæ and Nauplii, so abundant in February and March, are now scarce.

The Zoææ of Porcellana and of Portunidæ are particularly numerous.

Every year at this time the harbour is invaded by shoals of young brill (Rhombus lævis) in their pelagic stage.

June.-This is the month, par excellence, for Aurelia aurita and Ctenophores. Leptomedusæ also abound; large Obeliæ are now plentiful, and a new form, Laodice cruciata (Thaumantias pilosella of Forbes), makes its appearance.

The first specimens of pelagic Terebellid larvæ in gelatinous tubes may perhaps be taken.

NEW SERIES,-VOL. III, NO, III. 
The Gastropod larva Echinospira diaphana always occurs.

The Cladoceran Podon is generally abundant, but Evadne is generally still in mid-Channel. Sacculina Nauplii are plentiful.

Minute Oikopleuræ of the same year's brood are frequently abundant. After an exceptionally warm, calm spring the harbour may be invaded by hordes of Salps (Thalia democratica-mucronata).

July.-A transition is gradually effected during July between the distinctively summer and autumn faunas.

Rhizoselenia and Dinoflagellates (Ceratium, Peridinium) are common.

The Anthomedusæ are represented by numbers of Podocoryne carnea with some Sarsia eximia ; the Leptomedusæ by numbers of Laodice cruciata, Obelia, and (in the Channel) of Saphenia mirabilis.

The Siphonophore Muggiæa atlantica, which occurs during the earlier part of the year only in scanty numbers, becomes plentiful towards the end of this month.

The first specimens of Chætopterus larvæ may be taken.

Balanid Nauplii become again numerous, and Evadne arrives in large numbers.

Echinoid Plutei are to be obtained.

August.-In variety and intrinsic interest of the forms to be captured, this and the next month are perhaps the richest in the year,-a feature which accords well with the fact that during this month the sea temperature attains its maximum for the year.

The more oceanic element includes numbers of Radiolaria, Muggixa, young Geryonia appendiculata, Evadne (and perhaps Podon), and Doliolum Tritonis, - all of which, after a warm summer, may occur in plenty and even profusion.

Numbers of interesting larval forms are also taken, of which the chief perhaps are Müller's larva (in shoals towards the end of the month), Pilidium (abundantly), Annelid larvæ (Polygordius occasionally, Polydora, Pectinaria, Nerine, Magelona, Chætopterus), Gastropod larvæ (Rissoa, Ëirus, Cirropteron semilunare), Actinotrocha, Cirrhipede larvæ (Sacculina), Echinoderm larvæ (Plutei, large Bipinnariæ), Tornaria, and the larva of Amphioxus.

Conspicuous among Anthomedusæ are Amphinema Titania and Podocoryne (Dysmorphosa); and among Leptomedusæ, Saphenia mirabilis, Laodice cruciata, and small Obelix.

Dinoflagellates and diatoms (Rhizoselenia) are plentiful.

September.-The floating fauna during September differs very slightly from that of the preceding month.

The disappearance of the medusæ Laodice cruciata and Saphenia mirabilis is effected, and Willia stellata appears.

Almost all the other forms plentiful in August retain their abund- 
ance for the greater part of September, the possible exceptions being Radiolaria, Bipinnaria, and Tornaria.

On the other hand Terebellid larvæ are increasingly numerous; the larvæ of Muggiæa, of the Nemertine Cephalothrix, and of the Gephyrean Thalassema may be found; and Müller's larvæ, Pilidium, the larvæ of Magelona, Chætopterus, Rissoa, and Agirus are generally in the earlier part of the month especially plentiful.

Apparently characteristic of this period are the clouds of pelagic Rotifers which may occasionally be taken.

The diatom Chætoceros is especially abundant.

0ctober.-With the end of September an impoverishment of the fauna sets in, owing chiefly to the disappearance of the more oceanic element.

Chætoceros is the most plentiful diatom. The alga Halosphæra reappears. Dinoflagellates are abundant, and a few Radiolaria may still occur. The following medusæ may be present:-Cytæandra areolata, Eutima insignis, and large Irene pellucida.

Nemertine larvæ, including those of Cephalothrix, are numerous. Polychæte larvæ of the genera Polynoë, Chætopterus, Polydora, and Terebella are still present.

Larval Lamellibranchs and Cyphonautes are numerous, as indeed they seem to be during the greater part of the year.

Decapod larvæ are scarce, especially those of the Brachyura. Sagitta is generally present, and a few Plutei may be taken.

November.-The impoverishment continues. There is a great scarcity of medusæ, veligers, and Zoææ. The larvæ least rare are those of Polychætes, Cirrhipedes, Macrura, and Cyphonautes. Cephalothrix larvæ and Ophiurid Plutei may occur.

The diatom Coscinodiscus is present in profusion.

December.-Medusæ are still rare or even entirely absent. Annelid trochospheres and Opisthobranch veligers show signs of increasing numbers. Cyphonautes is present. 